\title{
Glypicans - A Brief Review
}

\author{
Kanupriya Gupta*, T.P. Chaturvedi and Jatin Gupta
}

Faculty of Dental Sciences, IMS, BHU, Varanasi (U.P.) 221005, India

\begin{abstract}
Glypicans (GPCs) are a family of proteoglycans that are bound to the cell surface by a glycosylphosphatidylinositol anchor. Six glypicans have been found in the mammalian genome (GPC1 to GPC6). Glypicans can be released from the cell surface by a lipase called Notum, and most of them are subjected to endoproteolytic cleavage by furin-like convertases. In vivo evidence published so far indicates that the main function of membrane-attached glypicans is to regulate the signaling of Wnts, Hedgehogs, fibroblast growth factors and bone morphogenetic proteins (BMPs). Surprisingly, the regulatory activity of glypicans in the Wnt, Hedgehog and BMP signaling pathways is only partially dependent on the heparan sulfate chains. It is obvious that our knowledge of glypican functions is still very limited despite the recent advances. A better understanding of these functions will make a significant contribution to the study of signaling pathways that play a very important role in developmental morphogenesis and several human diseases, including cancer.
\end{abstract}

Keywords: Glypican, Hedgehogs, BMP.

\section{INTRODUCTION}

Glypicans (GPC) are a family of heparin sulfate proteoglycans which are bound to cell membrane via a glycosyl-phosphatidylinositol (GPI) anchor [1]. GPC can reveal from the cell membrane by a lipase called Notum. It is involved in regulating different signaling pathways consisting of Wnt, Hedgehogs, fibroblast growth factors, and bone morphogenetic proteins [2, 3].

The glypican-mediated regulation of signaling occurs at the level of the interaction between the ligand and receptor, and glypicans can have either a stimulatory or inhibitory effect on signaling activity. The mammalian genome includes six glypicans (GPC1 to GPC6), and ortholog genes have been identified across Metazoans, including two in Drosophila (Dally and DIp) [4]. Glypicans do not display domains with obvious homology to characterized domains found in other proteins, suggesting that these proteoglycans have unique functions. Although the sequence identity between mammalian glypicans could be as low as $25 \%$, the three dimensional structure seems to be similar across the family [5]. Another feature shared by all glypicans is the position of the insertion sites for the GAG chains. These sites are located close to the Cterminus, suggesting that the GAG chains could mediate the interaction of these proteoglycans with other cell membrane proteins. The number of GAG insertion sites in each glypican, however, varies across the family (from 2 sites in GPC3, to 5 sites in GPC5). The functional implications of this variation are still not understood. In general, Glypicans display HS chains,

*Address correspondence to this author at the Faculty of Dental Sciences, IMS, BHU, Varanasi (U.P.) 221005, India; E-mail: drkanupriya12@gmail.com but GPC5 produced by rhabdomyosarcoma (RMS) cells also exhibits CS chains [6].

Due to their HS chain composition and their localization on the cell surface, they can regulate the cellular response to many heparin-binding growth factors, adhesion molecules and ECM components [7]. Glypicans are present in the cytoplasm and can be secreted to the ECM through the action of notum, a lipase that breaks the GPI anchors releasing the glypicans [8]. The alterations in this molecule have been identified in different congenital malformations and cancer [7].

In odontogenic tumors (OTs), glypican-1 is present in fibroblasts, in epithelial and tumor cells and also in its secreted form in the ECM. The immunoexpression in the fibroblasts is higher in those nearest to the tumor cells, suggesting that they might participate in the storage of heparin-depending growth factors, which are released by the heparanase at the beginning of infiltration and invasion processes and induce mitogenic stimulation of cancer cells. The intracellular presence of glypican-1 might be related to its capacity to act as a receptor for extracellular ligands such as growth factors [7].

The other member of the glypican family that has been studied in OTs is glypican-3, which seems to contribute in OT invasiveness and could be considered as a marker to distinguish aggressive from nonaggressive lesions [9].

The expression of Glypicans in head and neck tumors still needs to be explored more as only two studies have been recognized from the literature search. Thus, the aim of this review is to make readers 
understand the structure,function and mechanism of action of Glypican, so that it can be further incorporated in the studies and for better prognosis of the tumor.

\section{MECHANISM OF ACTION}

Depending on the biological context, glypicans can either stimulate or inhibit signaling activity. In the case of the stimulation of Wnt signaling, it has been proposed that the stimulatory mechanism is based on the ability of glypicans to facilitate and/or stabilize the interaction of Wnts with their signaling receptors, the Frizzled proteins. This hypothesis is based on the finding that glypicans can bind to Wnts and to Frizzleds [9] and that transfection of glypicans increases the Wnt-binding capacity of the transfected cells [9]. In the case of Hhs, it has been recently reported that GPC3 inhibits their signaling during development by competing with Patched, the $\mathrm{Hh}$ receptor, for $\mathrm{Hh}$ binding [11]. The binding of $\mathrm{Hh}$ to GPC3 triggers its endocytosis and degradation. On the other hand, it has been shown that the Drosophila glypican Dally-like protein stimulates $\mathrm{Hh}$ signaling, although the mechanism of this stimulatory activity remains unknown [12].

Because the HS chains have a strong negative charge, HS proteoglycans can interact in a rather promiscuous way with proteins that display positively charged domains. On this basis it was originally thought that the HS chains were essential for glypican activity. Indeed, this seems to be the case for the glypican-induced stimulation of FGF activity [13]. However, recent experimental evidence has demonstrated that the HS chains are only partially required for the regulatory activity of glypicans in $\mathrm{Hh}$, Wnt and BMP signaling [11,13]. Furthermore, Hh has been shown to bind to the core protein of GPC3 with high affinity [11].

\section{CHARACTERISTIC STRUCTURAL FEATURES}

The three-dimensional structure of glypicans is highly conserved across the family, as the localization of 14 cysteine residues is preserved in all family members [14]. A weak identity between a fragment that extends approximately from residue 200 to residue 300 of glypicans and the cysteine-rich domain of Frizzled proteins has been reported [15]. Whether this has functional implications is still unknown, however another interesting structural feature shared by all glypicans is the insertion sites for the heparan sulfate (HS) chains, which are located close to the carboxyl terminus. This places the HS chains close to the cell surface, suggesting that these chains could mediate the interaction of glypicans with other cell-surface molecules, including growth factor receptors.

\section{CONCLUSION}

One of the main issues that requires attention in the near future is the cellular and molecular basis of the context specificity that characterizes glypican activity. A further important topic of investigation will be the role of glypicans in morphogen gradient formation. We still do not understand the precise role of these proteins in regulating morphogen movement. Furthermore, whether glypicans are involved in this process in mammals remains to be investigated. It is obvious that our knowledge of glypican functions is still very limited despite the recent advances. A better understanding of these functions will make a significant contribution to the study of signaling pathways that play a very important role in developmental morphogenesis and several human diseases, including cancer.

\section{CONFLICT OF INTEREST}

The authors declare no conflict of interest.

\section{ACKNOWLEDGEMENT}

Authors acknowledge DST Purse 5050 program.

\section{ETHICAL}

Ethical clearance was obtained.

\section{REFERENCES}

[1] Filmus J, Selleck SB. Glypicans: proteoglycans with a surprise. J Clin Invest 2001; 108(4): 497-501. https://doi.org/10.1172/JCl200113712

[2] Torisu Y, Watanabe A, Nonaka A, et al. Human homolog of NOTUM, overexpressed in hepatocellular carcinoma, is regulated transcriptionally by $\beta$-catenin/TCF. Canc Sci 2008 ; 99(6): 1139-1146.

https://doi.org/10.1111/j.1349-7006.2008.00814.x

[3] De Cat B, Muyldermans S-Y, Coomans C, et al. Processing by proprotein convertases is required for glypican-3 modulation of cell survival, Wnt signaling, and gastrulation movements. J Cell Biol 2003; 163(3): 625-635. https://doi.org/10.1083/jcb.200302152

[4] Filmus J, Capurro M. The glypican family. In: Karamanos, Nikos K. (Ed.), Extracellular Matrix: Pathobiology and Signaling. De Gruyter, Berlin/Boston, 2012; pp. 209-220.

[5] Filmus J, et al. Glypicans. Genome Biol 2008; 9: 224. https://doi.org/10.1186/gb-2008-9-5-224

[6] Li $\mathrm{F}$, et al. Glypican-5 stimulates rhabdomyosarcoma cell proliferation by activating Hedgehog signaling. J Cell Biol 2011; 192: 691-704.

https://doi.org/10.1083/jcb.201008087 
[7] Bologna-Molina R, Mosqueda-Taylor A, Molina-Frechero N. Differential expression of glypican-1 in ameloblastoma variants. Appl Immunohistochem Mol Morphol 2015; 23: 15360. https://doi.org/10.1097/PAI.0000000000000042

[8] Filmus J, Capurro M, Rast J. Glypicans. Genome Biol 2008; 9: 224.

https://doi.org/10.1186/gb-2008-9-5-224

[9] Mendes RB, Dias RB, Figueiredo AL, Gurgel CA, Santana Filho M, Melo LA, et al. Glypican-3 distinguishes aggressive from non-aggressive odontogenic tumors: A preliminary study. J Oral Pathol Med 2017; 46: 297-300. https://doi.org/10.1111/jop.12501

[10] Capurro M, Xiang YY, Lobe C, Filmus J. Glypican-3 promotes the growth of hepatocellular carcinoma by stimulating canonical Wnt signaling. Cancer Res 2005; 6655: 6245-6254.

https://doi.org/10.1158/0008-5472.CAN-04-4244

[11] Capurro MI, Xu P, Shi W, Li F, Jia A, Filmus J. Glypican-3 inhibits hedgehog signaling during development by competing with Patched for Hedgehog binding. Dev Cell 2008; 1144: 700-711. https://doi.org/10.1016/j.devcel.2008.03.006
[12] Lum L, Yao S, Mozer B, Rovescalli A, Von Kessler D, Nirenberg M, Beachy PA. Identification of hedgehog pathway components by RNAi in Drosophila cultured cells. Science 2003; 229999: 2039-2045.

https://doi.org/10.1126/science. 1081403

[13] Song $\mathrm{HH}$, Shi W, Filmus J. OCl-5/rat glypican-3 binds to fibroblast growth factor-2 but not to insulin -like growth factor2. J Biol Chem 1997; 227722: 7574-7577. https://doi.org/10.1074/jbc.272.12.7574

[14] Veugelers $M$, De Cat $B$, Ceulemans $H$, Bruystens AM, Coomans C,Durr J, Vermeesch J, Marynen P, David G. Glypican-6, a new member of the glypican family of cell surface proteoglycans. J Biol Chem 1999; 227744: 2696826977. https://doi.org/10.1074/jbc.274.38.26968

[15] Topczewsky J, Sepich DS, Myers DC, Walker C, Amores A Lele Z, Hammerschmidt M, Postlethwait J, Solnica-Krezel L. The zebrafish glypican Knypek controls cell polarity during gastrulation movements of convergent extension. Dev Cell 2001; 11: 251-264.

https://doi.org/10.1016/S1534-5807(01)00005-3

Received on 01-12-2019

Accepted on 27-12-2019

Published on 30-12-2019

https://doi.org/10.30683/1927-7229.2019.08.09

(C) 2019 Gupta et al.; Licensee Neoplasia Research.

This is an open access article licensed under the terms of the Creative Commons Attribution Non-Commercial License (http://creativecommons.org/licenses/by-nc/3.0/) which permits unrestricted, non-commercial use, distribution and reproduction in any medium, provided the work is properly cited. 